УДК 633.11:631.461

(C) 2013

\author{
Шевніков Д. М., аспірант
}

(науковий керівник - доктор сільськогосподарських наук, професор Г. П. Жемела)

Полтавська державна аграрна академія

\title{
ВПЛИВ МІНЕРАЛЬНИХ ДОБРИВ ТА БІОПРЕПАРАТІВ НА ЯКІСТЬ ЗЕРНА ПШЕНИЦІ ТВЕРДОЇ ЯРОЇ
}

\section{Рецензент - доктор сільськогосподарських наук, професор С. М. Каленська}

Застосування мінеральних добрив та інокуляиії насіння пшениці твердої ярої біопрепаратами позитивно вплинуло на фізичні показники якості. Натура зерна пшениці була більшою на ділянках з інокульованим насінням «Діазофітом» $i$ «Поліміксобактерином»на фоні удобрення «солома $+N_{10}$ на тонну побічної продукиії» 789 г/л; за використання циих двох препаратів окремо отримали, відповідно, 788 і 792 г/л, контроль (без добрив та інокуляції) - 762 г/л. За внесення мінеральних добрив $N_{45} P_{45} K_{30}$ натура зерна становила без інокуляиії 781 г/л, а за ї̈ проведення «Поліміксобактерином» - 783, «Діазофітом» - 786, сумісного використання циих двох препаратів - 786 г/л.

Ключові слова: пшеничя тверда яра, мінеральні добрива, «Поліміксобактерин», «Діазофіт», скловидність, маса 1000 зерен, натура зерна.

Постановка проблеми. Умовно показники якості зерна поділяють на три групи: фізичні, біохімічні, технологічні. До фізичних належать натура, маса 1000 зерен, склоподібність, вирівняність, колір і запах зерна та деякі інші. Під натурою розуміють масу певного об'єму зерна (частіше 1 л). Для зерна пшениці озимої вона коливається від 725 (іноді нижче) до 785 г/л. У комплексі натура характеризує зернину - іiі виповненість, шорсткість, опушеність. Рівень базисної кондиції для натури зерна пшениці озимої становить 755 г/л. Натура може використовуватись як ознака, що вказує на борошномельні якості зерна. У випадку, коли натура не перевищує 750 г/л, зерно має занижений вихід борошна, коли вона вища 750 г/л, то ця тенденція відсутня. Водночас від натури залежать i технологічні властивості. За показника меншого 700 г/л значно погіршуються хлібопекарські властивості, м'якуш хліба є сірим і з гіршим смаком. Зменшення натури зерна може бути попередженням зниження врожайності зерна пшениці.

Аналіз основних досліджень і публікацій, у яких започатковано розв'язання проблеми. Висока продуктивність і якість зерна досягаються за повного забезпечення рослин елементами живлення та інших факторів на всіх етапах росту й розвитку рослин [1-3].
Враховуючи способи, які позитивно або негативно впливають на врожайність, можна суттєво зменшити негативну дію метеорологічних умов $\mathrm{i}$ цілеспрямовано використовувати елементи технології вирощування, що їх може контролювати людина $[4,5]$. У зв'язку з цим неабияке значення має застосування агротехнічних заходів, спрямованих на максимальну економію використання грунтової вологи в процесі формування врожайності. Важливою умовою зменшення коефіцієнта водоспоживання рослин $\epsilon$ створення оптимального режиму мінерального живлення, що забезпечує найкращий розвиток рослин по етапах органогенезу й отримання високої врожайності та якості зерна пшениці [6].

Застосування біологічних і хімічних засобів у технологіях вирощування пшениці позитивно впливає на ріст і розвиток окремих органів та рослинного організму в цілому, тому необхідною умовою їхнього використання $є$ комплексне вивчення впливу на формування врожайності та якості зерна [7].

Мета і завдання дослідження. Метою наших досліджень було встановити норми внесення мінеральних добрив за умови застосування біопрепаратів, що сприяють оптимальному розвитку надземної і підземної частин рослин і забезпечують формування стабільно великої врожайності зерна високої якості незалежно від погодних умов.

Завдання досліджень - вивчити особливості росту, розвитку рослин за використання передпосівної обробки насіння різними біологічними препаратами залежно від рівня мінерального живлення та встановити їхнє оптимальне співвідношення для забезпечення формування стабільної врожайності зерна пшениці твердої ярої 3 високими якісними характеристиками.

Матеріали і методи досліджень. Основні дослідження проводили на дослідному полі Полтавського інституту АПВ ім. М. І. Вавилова в 2010-2012 роках. Вивчали вплив передпосівної обробки насіння мікробіологічними препаратами залежно від розрахованого балансовим методом 


\section{СТОРІНКА МОЛОДОГО ВЧЕНОГО}

фону мінерального живлення рослин на врожайність 3 т/га зерна. Вивчали шість фонів мінерального живлення: без добрив - контроль; $\mathrm{N}_{45} ; \mathrm{P}_{45} \mathrm{~K}_{30}$; $\mathrm{N}_{45} \mathrm{P}_{45} \mathrm{~K}_{30}$; $\mathrm{N}_{23} \mathrm{P}_{23} \mathrm{~K}_{15}$; солома попередника $+\mathrm{N}_{10}$ на кожну тонну побічної продукції.

Результати досліджень. Натура зерна, як і інші показники якості, відрізнялися за роками досліджень. Найбільшим цей показник був в умовах 2011 року, меншим - у 2010 та 2012 роках, що пояснюємо впливом агрокліматичних умов місцевості. У середньому за три роки досліджень найбільша натура зерна пшениці встановлена на ділянках, висіяних інокульованим насінням «Діазофітом» та «Поліміксобактерином» на фоні удобрення «солома $+\mathrm{N}_{10}$ на тонну побічної продукції» - 789 г/л; за використання цих двох препаратів окремо отримали врожайність, відповідно, 788 і 792 г/л.

Найменша натура зерна була одержана на контрольному варіанті (без добрив та інокуляції) 762 г/л.

Ефективним засобом підвищення продуктивності пшениці твердої ярої $\epsilon$ внесення мінеральних добрив $\mathrm{N}_{45} \mathrm{P}_{45} \mathrm{~K}_{30}$, натура зерна становила без інокуляції - 781 г/л, а за ії проведення «Поліміксобактерином» - 783, «Діазофітом»- 786, за сумісного використання двох препаратів - 786 г/л (табл. 1).

Склоподібність (консистенція ендосперму) характеризує структурно-механічні властивості зерна, що залежать від щільності упакування в ендоспермі крохмальних зерен та їх зцементованості білками. Повна скловидність характеризує наявність повністю склоподібних зерен. У розрізі склоподібні зерна мають полиск і схожі на прозорі. Загальна склоподібність характеризується сумою повністю склоподібних і напівсклоподібних зерен. Зріз борошнистого зерна нагадує поверхню крейди. Зерно пшениці може бути склоподібним - із повністю склоподібним ендоспермом, борошнистим - із повністю борошнистим ендоспермом та частково склоподібним - 3 ендоспермом частково борошнистим або склоподібним. Партія зерна вважається склоподібною за $75 \%$ і вище, напівсклоподібною - за 40-75 \% і борошнистою - менше $40 \%$. За цим показником можна судити про вміст білка та технологічні показники якості зерна. За його зростання спостерігається вищий вміст білка й кращі технологічні властивості. Вихід борошна із високосклоподібних зерен більший. Склоподібність у цілому належить до видових і сортових ознак (тверді пшениці більш склоподібніші, ярі пшениці склоподібніші, ніж озимі).

Результати досліджень вказують, що доцільним
$€$ передпосівна інокуляція насіння пшениці твердої ярої «Поліміксобактерином» i «Діазофітом» на фоні внесення мінеральних добрив $\mathrm{N}_{45} \mathrm{P}_{45} \mathrm{~K}_{30}$, так як за результатами трьохрічних досліджень склоподібність зерна становила 86-89\%, що більше ніж на ділянках без використання мінеральних добрив та біопрепаратів (табл. 2).

Раціональним способом підвищення врожайності пшениці твердої ярої є застосування варіанту удобрення «солома $+\mathrm{N}_{10}$ на тонну побічної продукції» $з$ обов'язковою обробкою насіння перед сівбою сумішшю цих двох біопрепаратів 83-85\%, внесення мінеральних добрив у дозі $\mathrm{N}_{23} \mathrm{P}_{23} \mathrm{~K}_{15}$ було також ефективним - 82-85\%, $\mathrm{N}_{45}-87-90, \mathrm{P}_{45} \mathrm{~K}_{30}-$ $82-83 \%$.

Маса 1000 зерен характеризує виповненість зерна і вказує на його величину. Крупніше зерно має більшу масу 1000 зерен. Вважається, що зерно 3 більшим показником має кращі технологічні властивості - вищий вихід готової продукції (борошна, крупи). Встановлена залежність між масою 1000 зерен та вмістом білка і клейковини. Між білковістю та масою зерна існує помірна, але достовірна обернена залежність. Щупле зерно за вищого вмісту в ньому білка має гірші харчові якості, тому що білок, в основному, концентрується в периферійних частинах, які відходять при розмелі.

Обернена залежність між масою 1000 зерен i вмістом клейковини не характерна для крупного зерна, але коли вона зменшується нижче 32-34 г, то дрібні зерна характеризуються збільшеним вмістом клейковини. За масою 1000 зерен пшеницю поділяють на 4 групи: 3 високою вагою (вище 30 г), 3 вагою вище середньої (25-30 г), середньою вагою (22-25 г), нижче середньої (менше 22 г). Зазвичай пшениці з високим показником дають світліше борошно й білішу м'якушку хліба (табл. 3).

На останніх етапах росту і розвитку рослин більший рівень урожайності досягається за рахунок кращої виповненості зерна, тобто формування крупного, добре розвиненого зерна. Виповненість зерна найкраще характеризується таким показником як маса 1000 зерен. Як доводять дослідження, між виповненістю зерна й обсягом врожаю в більшості випадків існує пряма залежність.

Найбільшу масу 1000 зерен мають рослини, вирощені у сприятливих метеорологічних умовах в період наливу та достигання зерна. Дослідами встановлено, що пшениця яра особливо чутлива до відхилень температур від оптимальної в фазу «вихід у трубку - колосіння». Досить несприятливо на формування врожаю впливають високі температури в період наливу зерна. 
СТОРІНКА МОЛОДОГО ВЧЕНОГО

\section{1. Натура зерна пиениці твердої ярої залежно від дії мінеральних добрив та біопрепаратів, г/л}

\begin{tabular}{|c|c|c|c|c|c|}
\hline \multirow[b]{2}{*}{$\begin{array}{c}\text { Варіанти } \\
\text { удобрення }\end{array}$} & \multirow[b]{2}{*}{ Роки } & \multicolumn{4}{|c|}{ Інокуляція зерна мікробіопрепаратами } \\
\hline & & $\begin{array}{c}\text { без } \\
\text { інокуляції }\end{array}$ & $\begin{array}{l}\text { «Полі- } \\
\text { міксобак- } \\
\text { терин» }\end{array}$ & «Діазофіт» & $\begin{array}{c}\text { суміш «Полі- } \\
\text { міксобактерину»» } \\
\text { та «Діазофіту» }\end{array}$ \\
\hline \multirow[t]{4}{*}{ 1. Без добрив } & 2010 & 760 & 770 & 770 & 776 \\
\hline & 2011 & 765 & 780 & 790 & 785 \\
\hline & 2012 & 760 & 780 & 770 & 780 \\
\hline & Середнє & 762 & 777 & 779 & 780 \\
\hline \multirow{4}{*}{ 2. $\mathrm{N}_{45} \mathrm{P}_{45} \mathrm{~K}_{30}$} & 2010 & 780 & 780 & 785 & 780 \\
\hline & 2011 & 795 & 790 & 793 & 790 \\
\hline & 2012 & 770 & 780 & 780 & 789 \\
\hline & Середнє & 781 & 783 & 786 & 786 \\
\hline \multirow{4}{*}{$\begin{array}{l}\text { 3. Солома }+\mathrm{N}_{10} \\
\text { на тонну побічної } \\
\text { продукції }\end{array}$} & 2010 & 785 & 785 & 780 & 785 \\
\hline & 2011 & 785 & 795 & 795 & 792 \\
\hline & 2012 & 780 & 796 & 790 & 790 \\
\hline & Середнє & 783 & 792 & 788 & 789 \\
\hline \multirow[t]{4}{*}{ 4. $\mathrm{N}_{23} \mathrm{P}_{23} \mathrm{~K}_{15}$} & 2010 & 780 & 780 & 780 & 785 \\
\hline & 2011 & 785 & 795 & 795 & 790 \\
\hline & 2012 & 760 & 780 & 780 & 790 \\
\hline & Середнє & 775 & 785 & 785 & 788 \\
\hline \multirow{4}{*}{ 5. $\mathrm{N}_{45}$} & 2010 & 785 & 790 & 780 & 790 \\
\hline & 2011 & 790 & 790 & 785 & 795 \\
\hline & 2012 & 770 & 795 & 790 & 795 \\
\hline & Середнє & 781 & 791 & 785 & 793 \\
\hline \multirow[t]{4}{*}{ 6. $\mathrm{P}_{45} \mathrm{~K}_{30}$} & 2010 & 785 & 800 & 787 & 789 \\
\hline & 2011 & 790 & 790 & 790 & 790 \\
\hline & 2012 & 775 & 794 & 785 & 790 \\
\hline & Середнє & 783 & 795 & 787 & 789 \\
\hline
\end{tabular}

2. Склоподібність зерна пшениці твердої ярої залежсно від дії мінеральних добрив та біопрепаратів за різних умов вирощування, \%

\begin{tabular}{|c|c|c|c|c|c|}
\hline \multirow[b]{2}{*}{ Варіанти удобрення } & \multirow[b]{2}{*}{ Роки } & \multicolumn{4}{|c|}{ Інокуляція зерна мікробіопрепаратами } \\
\hline & & $\begin{array}{c}\text { без } \\
\text { інокуляції }\end{array}$ & $\begin{array}{c}\text { «Полі- } \\
\text { міксобак- } \\
\text { терин» }\end{array}$ & «Діазофіт» & $\begin{array}{c}\text { суміш «Полі- } \\
\text { міксобактерину» } \\
\text { та «Діазофіту» }\end{array}$ \\
\hline 1 & 2 & 3 & 4 & 5 & 6 \\
\hline \multirow[t]{4}{*}{ 1. Без добрив } & 2010 & 73 & 76 & 78 & 79 \\
\hline & 2011 & 80 & 85 & 85 & 82 \\
\hline & 2012 & 80 & 84 & 85 & 80 \\
\hline & Середнє & 78 & 82 & 83 & 80 \\
\hline \multirow[t]{4}{*}{ 2. $\mathrm{N}_{45} \mathrm{P}_{45} \mathrm{~K}_{30}$} & 2010 & 91 & 90 & 90 & 92 \\
\hline & 2011 & 83 & 85 & 87 & 80 \\
\hline & 2012 & 83 & 85 & 90 & 79 \\
\hline & Середнє & 86 & 87 & 89 & 84 \\
\hline \multirow{4}{*}{$\begin{array}{l}\text { 3. Солома }+\mathrm{N}_{10} \\
\text { на тонну побічної } \\
\text { продукції }\end{array}$} & 2010 & 76 & 78 & 85 & 81 \\
\hline & 2011 & 85 & 80 & 86 & 84 \\
\hline & 2012 & 84 & 90 & 85 & 84 \\
\hline & Середнє & 82 & 83 & 85 & 83 \\
\hline \multirow{4}{*}{ 4. $\mathrm{N}_{23} \mathrm{P}_{23} \mathrm{~K}_{15}$} & 2010 & 79 & 82 & 86 & 86 \\
\hline & 2011 & 84 & 80 & 85 & 75 \\
\hline & 2012 & 83 & 85 & 85 & 84 \\
\hline & Середнє & 82 & 82 & 85 & 82 \\
\hline
\end{tabular}


СТОРІНКА МОЛОДОГО ВЧЕНОГО

\begin{tabular}{|l|c|c|c|c|c|}
\hline \hline \multicolumn{1}{c}{} & \multicolumn{4}{c}{ Продовження табл. 2 } \\
\hline \multirow{3}{*}{$5 . \mathrm{N}_{45}$} & 2 & 3 & 4 & 5 & 6 \\
& 2010 & 87 & 86 & 88 & 88 \\
& 2011 & 85 & 85 & 90 & 80 \\
& 2012 & 81 & 90 & 91 & 80 \\
\cline { 2 - 6 } & Середнє & 84 & 87 & 90 & 83 \\
\hline \multirow{3}{*}{$\mathrm{P}_{45} \mathrm{~K}_{30}$} & 2010 & 68 & 77 & 71 & 80 \\
& 2011 & 80 & 90 & 90 & 90 \\
& 2012 & 88 & 80 & 85 & 80 \\
\cline { 2 - 6 } & Середнє & 79 & 82 & 82 & 83 \\
\hline
\end{tabular}

3. Маса 1000 зерен пшениці твердої ярої залежно від дії мінеральних добрив та біопрепаратів за різних умов вирощування, г

\begin{tabular}{|c|c|c|c|c|c|}
\hline \multirow[b]{2}{*}{$\begin{array}{c}\text { Варіанти удоб- } \\
\text { рення }\end{array}$} & \multirow[b]{2}{*}{ Роки } & \multicolumn{4}{|c|}{ Інокуляція зерна мікробіопрепаратами } \\
\hline & & $\begin{array}{c}\text { без } \\
\text { інокуляції }\end{array}$ & $\begin{array}{c}\text { «Полі- } \\
\text { міксобак- } \\
\text { терин» }\end{array}$ & «Діазофіт» & $\begin{array}{c}\text { суміш «Полі- } \\
\text { міксобактерину» } \\
\text { та «Діазофіту» }\end{array}$ \\
\hline \multirow[t]{4}{*}{ 1. Без добрив } & 2010 & 37,4 & 36,8 & 36,6 & 37,8 \\
\hline & 2011 & 39,2 & 38,5 & 39,5 & 38,0 \\
\hline & 2012 & 34,0 & 37,4 & 36,4 & 37,8 \\
\hline & Середнє & 36,9 & 37,6 & 37,5 & 37,8 \\
\hline \multirow{4}{*}{ 2. $\mathrm{N}_{45} \mathrm{P}_{45} \mathrm{~K}_{30}$} & 2010 & 37,8 & 37,8 & 37,6 & 36,6 \\
\hline & 2011 & 40,1 & 40,3 & 38,5 & 37,0 \\
\hline & 2012 & 35,2 & 38,0 & 36,7 & 39,0 \\
\hline & Середнє & 37,7 & 38,7 & 37,6 & 37,5 \\
\hline \multirow{4}{*}{$\begin{array}{l}\text { 3. Солома }+\mathrm{N}_{10} \\
\text { на тонну побіч- } \\
\text { ної продукції }\end{array}$} & 2010 & 37,6 & 38,2 & 38,2 & 38,1 \\
\hline & 2011 & 38,1 & 39,2 & 39,5 & 38,0 \\
\hline & 2012 & 36,0 & 38,3 & 37,3 & 38,8 \\
\hline & Середнє & 37,2 & 38,6 & 38,3 & 38,3 \\
\hline \multirow[t]{4}{*}{ 4. $\mathrm{N}_{23} \mathrm{P}_{23} \mathrm{~K}_{15}$} & 2010 & 38,0 & 38,5 & 38,5 & 36,0 \\
\hline & 2011 & 38,1 & 39,1 & 39,2 & 38,5 \\
\hline & 2012 & 34,8 & 37,8 & 36,8 & 38,4 \\
\hline & Середнє & 37,0 & 38,5 & 38,2 & 37,6 \\
\hline \multirow[t]{4}{*}{ 5. $\mathrm{N}_{45}$} & 2010 & 37,6 & 37,2 & 36,4 & 36,0 \\
\hline & 2011 & 38,0 & 39,0 & 38,7 & 39,2 \\
\hline & 2012 & 35,7 & 38,4 & 37,1 & 39,0 \\
\hline & Середнє & 37,1 & 38,2 & 37,4 & 38,1 \\
\hline \multirow{4}{*}{ 6. $\mathrm{P}_{45} \mathrm{~K}_{30}$} & 2010 & 38,0 & 37,5 & 38,5 & 37,6 \\
\hline & 2011 & 39,5 & 39,5 & 40,1 & 38,3 \\
\hline & 2012 & 35,6 & 38,0 & 37,0 & 38,8 \\
\hline & Середнє & 37,7 & 38,3 & 38,5 & 38,2 \\
\hline
\end{tabular}

Значення цього показника змінювалося залежно від погодних умов та факторів інтенсифікації. Найбільшою вона була в 2011 році за внесення мінеральних добрив $\mathrm{N}_{45} \mathrm{P}_{45} \mathrm{~K}_{30}(40,1$ г), а за умови застосування додатково «Поліміксобактерину» 40,3 грама. Мінеральні добрива сприяли підвищенню маси 1000 насінин до 37,0-37,7 г за внесення мінеральних добрив різних варіантів, «Поліміксобактерину» - до 37,6 г, «Діазофіту» - до 37,5 , суміші препаратів - до 37,8 г порівняно 3 контролем $(36,9$ г). На удобрених варіантах об- робка насіння біопрепаратами збільшувала масу 1000 насінин до 38,3-38,6 г. Біопрепарати ефективніше впливали на крупність насіння, ніж мінеральні добрива.

\section{Висновки:}

1. Фізичні показники якості зерна пшениці твердої ярої залежать від погодних умов року, застосування мінеральних добрив та мікробіопрепаратів. Натура зерна пшениці була більшою на ділянках з інокульованим насінням «Діазофітом» $\mathrm{i}$ «Поліміксобактерином» на фоні удобрен- 


\section{СТОРІНКА МОЛОДОГО ВЧЕНОГО}

ня «солома $+\mathrm{N}_{10}$ на тонну побічної продукції» 789 г/л; за використання цих двох препаратів окремо отримали врожайність, відповідно, 788 і 792 г/л, контроль (без добрив та інокуляції) 762 г/л. За внесення мінеральних добрив $\mathrm{N}_{45} \mathrm{P}_{45} \mathrm{~K}_{30}$ натура зерна становила без інокуляції 781 г/л, а за ii проведення «Поліміксобактерином» - 783, «Діазофітом» - 786, за сумісного використання цих двох препаратів - 786 г/л.

2. За використання біопрепаратів на фоні внесення мінеральних добрив $\mathrm{N}_{45} \mathrm{P}_{45} \mathrm{~K}_{30}$ склоподіб-

\section{БІБЛІОГРАФІЯ}

1. Голик В. С. Яровая пшеница / В. С. Голик // Пшеница. - К. : Урожай, 1989. - С. 281-307.

2. Голик B. C. Создание сортов яровой мягкой и твердой пшеницы с высокими хлебопекарными и макаронными свойствами в Институте растениеводства им. В. Я. Юрьева / В. С. Голік // Наукові основи стабілізації виробництва продукції рослинництва. - Х., 2001. - С. 19-28.

3. Грицай А. Д., Камінський В. Ф., Романюк П. В. [ma iн.]. Чи є альтернатива інтенсивним технологіям вирощування сільськогосподарських культур // Землеробство. - 1994. - Вип. 69. C. 23.

4. Жемела Г. П. Поліпшення якості зерна польових культур за допомогою використання ність зерна становила 86-89\%, за удобрення «солома $+\mathrm{N}_{10}$ на тонну побічної продукції» - 8385 \%. Мінеральні добрива сприяли підвищенню маси 1000 зернин до 37,0-37,7 г, за використання «Діазофіту» - 37,5, «Поліміксобактерину» 37,6 г, суміші препаратів - 37,8 г порівняно з контролем $(36,9$ г). На удобрених варіантах обробка насіння біопрепаратами збільшувала масу 1000 зернин до 38,3-38,6 грама. Біопрепарати ефективніше впливали на крупність насіння, ніж мінеральні добрива.

добрив / Г. П. Жемела, Г. Г. Дуда // Удобрення польових культур при інтенсивних технологіях вирощування. - К. : Урожай, 1990. - С. 176-190.

5. Мишустин Е. Н. Микроорганизмы и продуктивность земледелия / Е. Н. Мишустин. - М. : Наука, 1972. $-243 \mathrm{c}$.

6. Чуб М. П. Влияние удобрений на качество зерна яровой пшеницы / М.П. Чуб. - М. : Россельхозиздат, 1980. - 69 с.

7. Шевченко О. I. Продуктивність і якість зерна пшениці ярої за різних способів застосування фізіологічно активних речовин / О. І. Шевченко // Наукові праці Полтавської державної аграрної академії. - Полтава, 2005. - Т. 4 (23). C. $280-285$. 